\title{
SOCIAL CULTURE IMPACT AND VALUE CHANGES OF BATIK TOURISM VILLAGE: A CASE STUDY OF PESINDON-INDONESIA BATIK TOURISM VILLAGE
}

\author{
Dian KUSUMAWATI \\ Universitas Negeri Semarang, Graduate School, Indonesia, e-mail: diankusumawati22@ gmail.com \\ RUSDARTI* \\ Universitas Negeri Semarang, Graduate School, Indonesia, e-mail: rusdarti@mail.unnes.ac.id \\ Dewi Liesnoor SETYOWATI \\ Universitas Negeri Semarang, Graduate School, Indonesia, e-mail: dewiliesnoorsetyowati@gmail.com \\ Eko HANDOYO \\ Universitas Negeri Semarang, Graduate School, Indonesia, e-mail: ekohandoyo@mail.unnes.ac.id
}

\begin{abstract}
Citation: Kusumawati, D., Rusdarti, Setyowati, D.L., \& Handoyo, E. (2022). SOCIAL CULTURE IMPACT AND VALUE CHANGES OF BATIK TOURISM VILLAGE: A CASE STUDY OF PESINDON-INDONESIA BATIK TOURISM VILLAGE. GeoJournal of Tourism and Geosites, 40(1), 89-95. https://doi.org/10.30892/gtg.40110-806
\end{abstract}

\begin{abstract}
The development of batik tourism villages has an important role in the development of sustainable tourism. On the other hand, it also has an impact on a paradigm shift in socio-cultural impacts and changes in community values. Many studies examine the importance of developing a tourist village, but studies that discuss how the impact of developing a batik tourism village on socio-cultural changes and changes in values have not been widely studied. This study aims to analyze the socio-cultural impact and value changes in the Pesindon batik tourism village after the establishment of Pesindon as a batik tourism village in Pekalongan City. This study uses a qualitative approach involving informants as the main source of information and supporting informants. Data collection used the interview method on 15 respondents from Pesindon-Indonesia batik tourism village. Also, document analysis in the form of archives and other important documents was also carried out. The study results on the determination of Pesindon as a batik tourism village in Pekalongan City had a positive impact on the relationship between batik entrepreneurs and workers and batik entrepreneurs with the community. In addition, the relationship that occurs in the Pesind on batik tourism village leads to professional work to meet the needs of each individual, and batik is increasingly entrenched among the people of Pekalongan and increasingly popular in Indonesia. The establishment of the Pesindon batik tourism village provides positive benefits for the socio-cultural impact and changes in values and provides additional literature on life in society. The study results have implications for relevant stakeholders in the development of tourist villages to support sustainable touri sm.
\end{abstract}

Key words: socio-cultural impact, values changes, batik tourism village

$* * * * * *$

\section{INTRODUCTION}

Pekalongan is known as the city of batik because Pekalongan batik has a distinctive and varied pattern. Pekalongan City was included in the UNESCO creative city network in the category of crafts \& folk art in December 2014 and had the city branding of Pekalongan World's city of Batik. This branding shows that batik is a superior product and the pride of Pekalongan, which is one of the cultural heritage of the Indonesian nation. The Pekalongan government pays extra attention to areas that can see the growth and development of batik, which is increasingly promising. One of the efforts that can be seen physically with the emergence of batik shopping tourism is the batik tourism village. Batik tourism village is intended as an alternative to batik promotion and alternative recreation in Pekalongan City.

The international community has recognized batik as an intangible culture of human heritage originating from Indonesia through UNESCO. However, Indonesian batik is not a mass product that has a meaningless pattern. The inclusion of batik into the UNESCO list carries an obligation for Indonesia to protect the batik tradition so that we as Indonesians must be able to interpret and preserve this world's cultural icon and know the aspects of batik tradition that need to be protected (Komariah et al., 2020; Mahfud et al., 2019; Taufiqoh et al., 2018). Pesindon is one of the batik tourism villages, a hamlet area, and its territory is in Kergon Village, Pekalongan City, Central Java, Indonesia. The determination of the pesantren as a batik tourism village in Pekalongan City cannot be separated from the contribution of social capital that influences it. The contribution of social capital can be in the form of stimulation of interpersonal relationships (perception of authority, perception of closeness, and peer references), which are positively related to feelings of moral obligation and social capital, which is used as a conceptual tool to explore various aspects of life (Tulin et al., 2018; Xu et al., 2019; Zissi et al., 2010).

Social capital refers to the resources embedded in social bonds between individuals (Mahfud et al., 2020; Postelnicu and Hermes, 2018). Social capital is trust, networks, and institutions that influence economic behavior (Ali et al., 2015). In

\footnotetext{
* Corresponding author
} 
order to develop a clear and non-negative definition of social capital, it is essential to recognize the "weak ties" (Leyden and Link, 2015), otherwise referred to as the "radius of trust" (Fukuyama, 1997) or "bridging social capital" (Lancee, 2010), across subgroups within society (Wallis et al., 2004). Social capital is used as a tool in creating a batik tourism village (Affandi and Mursitama, 2018). In a study conducted by (Caldwell et al., 2017), the collaboration between the public and the private sector in coordinating the collective mobilization of resources can be used to create high social value. Furthermore, socioeconomic factors influence the formation of social capital (Gómez-Limón et al., 2014). Studies on social capital were conducted by (Hopkins, 2011; Mazumdar et al., 2018), where social capital has been conceptualized as features of social organization such as trust between citizens, reciprocal norms, and group membership that facilitate collective action, while social networks are used and how relationships are developed. Depends on group members' understanding of their collective identity. Social capital and social networks also influence the formation of the Pesindon batik tourism village.

A study on batik tourism villages by (Setyanto et al., 2015) about the importance of batik tourism villages contributing to the strengthening of the people's economic system, which has an impact on strengthening the national economy and, of course, making a significant contribution to the preservation of the nation's culture has obstacles both in terms of capital, marketing, and human resource management. Regarding cultural preservation, a study conducted by (Bahruddin and Nugraha, 2013) on the people of the Jetis batik village in Sidoarjo found findings of the efforts made by the Jetis batik village community to maintain written batik as a product of local culture and economic contribution. In line with the writings of Setyanto and Bahruddin, tourism potential that can be used as a business opportunity for the welfare of its people, one of which is the developing batik industry in Indonesia, in this case, research conducted by (Wahyuni et al., 2017) highlights the Tuban batik. Regional tourism development leads to regional development and contribution to local government revenues by considering the local potential that comes from nature, socio-culture, or economy to contribute to local governments while improving community welfare. The case study (Amijaya et al., 2019) was carried out on people in Klitren Village. The latter is moving towards realizing a cultural tourism village by promoting natural dye batik as one of the mainstays of its tourism products. The cultural tourism village plays a different role as an economic space and is embedded as a local identity. If it is associated with promoting culture and tourism, the aspect of local identity can be a strength and attachment. The community economy plays an essential role in realizing a people's economy that is creative, empowered, and attached to local potential. Studies on batik tourism villages have been carried out. However, studies that focus on the socio-cultural impact and changes in values from setting a village to a batik tourism village still require study.

Establishing a batik tourism village with various contributions does not necessarily mean that there will be no repercussions. The determination of the Pesindon batik tourism village resulted in changes in the social structure. It gave a socio-cultural impact and changes in values to the Pesindon village community because of the different mindsets generated by the community. The role of social norms in changing a person's behavior both from a psychological point of view in mobilizing social change involving support among social groups can have a negative impact on human psychology when accepting various norms that are different from what they have/live (Krupka and Weber, 2009; Nemoto, 1998). The existence of personality differences causes social dilemmas (Caldwell et al., 2017).

The development of Pesindon into a batik tourism village in Pekalongan City indirectly creates pros and cons between individuals and between individuals and groups, which results in socio-cultural impacts and changes in values and causes social change. Socio-cultural changes and changes in values are a symptom of changing social structures and cultural patterns in society. Social change is a common symptom that occurs throughout time in society; these symptoms occur following the nature and nature of humans who always want to make changes (Stoletov, 2016).

Social change refers to changes in social structure and social relations, while cultural change refers to changes in behavior patterns, including technology and dimensions of science, material, and non-material (Hatu, 2011). Social change is part of cultural change (Hjarvard, 2008). Changes in culture cover all parts, including art, science, technology, philosophy, and others, but these changes do not affect the social organization of the people (Adger et al., 2013). The scope of cultural change is broader than social change; however, in practice in the field, the two types of changes are challenging to separate (Cote and Nightingale, 2012). In the current era, every individual is trying to do social mobility, and this is because they believe that by doing social mobility, they will be better and happier so that they tend to be able to do the most suitable type of work, including the conditions that occur in the Pesindon batik tourism village.

Whether they are compatible with the determination of the Pesindon batik tourism village or not. Despite their different social backgrounds, social mobility is high, and they can still feel they have the same rights in achieving a higher social position (Stephens et al., 2014). The results of observations and interviews conducted on 6 - 14 February 2021 with the Pesindon secretariat as the resource person stated that the community felt the socio-cultural impact and changes in values. However, it was not fixed and had different views. Society cannot be seen as an "internality totally integrated entity," but must also be seen in existing segments or interest groups because the impact on one social group is not necessarily the same; it can even be contrary to the impact on other social groups. Likewise, regarding positive and unfavorable assessments, it is tough to generalize to assess societal changes because these positive and negative assessments are already value judgments, while these values are not always the same for all community groups.

That is, the positive and negative impacts need to be questioned, "positive for whom and negative for whom?" (Hermawan, 2016; Pitana, 2009); this is an exciting study to study. The problem that is quite clear is how the sociocultural impact and changes in values occurred in Pesindon Village after the establishment of Pesindon as a batik tourism village in Pekalongan City. Although the development of batik tourism villages has a socio-cultural impact and changes in values, it still needs clarity and special studies. This study aims to determine the socio-cultural impact and changes in the value of developing a batik tourism village in Pesindon Pekalongan, Indonesia. 


\section{MATERIAL AND METHODS}

Pesindon is a hamlet located in Kergon Village, Pekalongan City, Indonesia. The data sources in this study include informants. They are divided into two groups, key informants (primary sources of information) consisting of 15 informants (see Table 1), which include the Pesindon secretariat, batik workers, batik entrepreneurs, and the people of Kampung Pesindon to get the expected information, especially about socio - cultural impacts and changes in values so that the informants obtained come from trusted informants. In addition to key informants, supporting informants regarding the object of the study are entrepreneurs, workers, and residents of the Pesindon batik tourism village.

The data collected in this study used in-depth interviews and document analysis related to the Pesindon-Indonesia tourist village. Documents or library sources in books or appropriate literature are used as additional material to complete the data. The documents used are photographs, archives, and literature as additional material from documents related to the study. A phenomenological study was also carried out to reveal the phenomenon of the existence of Pesindon village. Data collection through archives consisting of the secretariat's organizational structure, population data, including photos depicting activities related to the problem, was also carried out in the study.

The data analysis technique used is by using procedural steps (Figure 1). For more details, see the following chart:

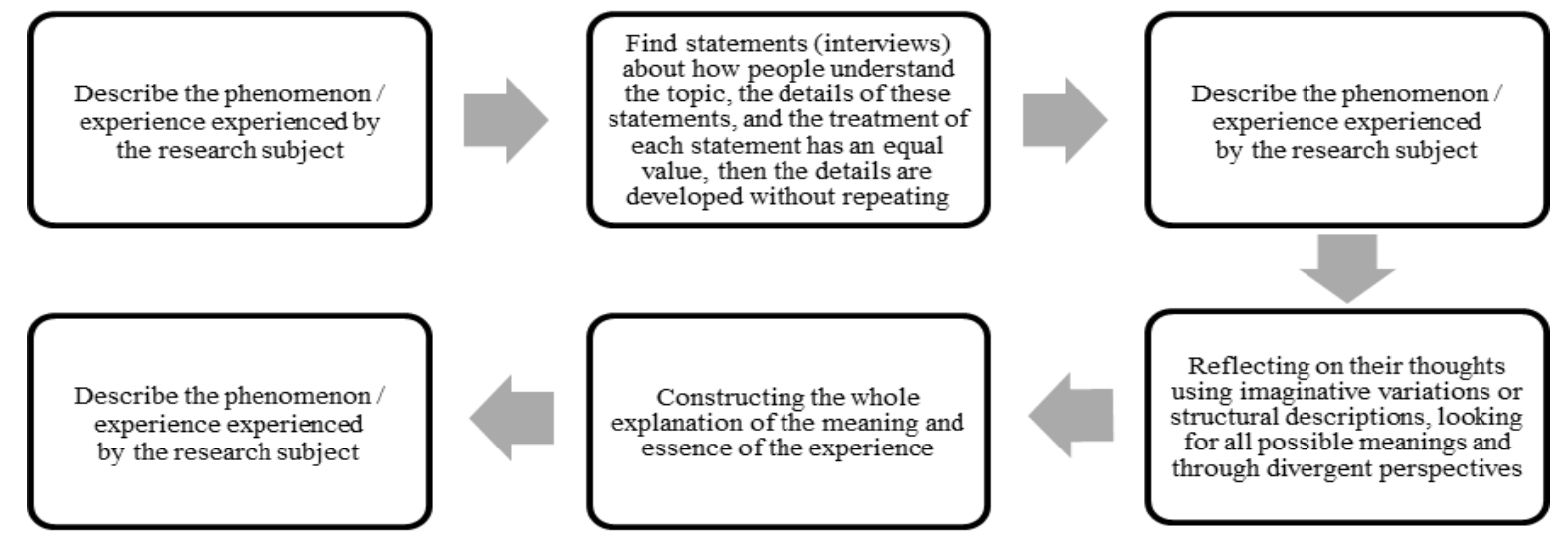

Figure 1. Creswell Model Data Analysis Techniques (2014)

The validity of this study uses the triangulation technique as a data checking technique. The triangulation technique used in this research is theoretical triangulation, where the data are taken is following Bourdieu's theory with social capital construction, concept structure triangulation, and source triangulation (Bourdieu, 1986). The triangulation technique used in this study is an examination technique by utilizing sources, which means comparing and checking back the degree of confidence of the information obtained.

\section{RESULTS AND DISCUSSION}

\section{Socio-Cultural Impact}

The determination of Pesindon as a batik tourism village in Pekalongan City has resulted in socio-cultural impacts that affect social life. Social impact assessment is defined as "the process of identifying the future consequences of current or proposed actions related to individuals, organizations and macro-social systems" (Becker, 2001; Mahmoudi et al., 2013). Interpersonal relationship stimuli (perceived authority, perceived closeness, and peer references) were positively related to feelings of moral obligation (Xu et al., 2019). Public-private collaboration coordinates the collective mobilization of resources to excel in sector value creation because it creates social value (Caldwell et al., 2017). The determination of the Pesindon batik tourism village has a more precise direction if there is good collaboration to create social values and other impacts.

The determination of Pesindon village in Pekalongan city as a batik tourism village has implications for socio-cultural conditions and changes in values. It indirectly affects social life and the current economy. This includes the board's composition role in the company (Johnson et al., 2013). The role of social capital bonds predicts complex project outcomes, where different types of social capital bonds produce different effects (Moore et al., 2018). Personality differences cause a dilemma in which the resulting differences in views encourage a person to think ahead and develop to initiate to realize the formation of a tourist village with the support of adequate environmental potential (Harris, 1995). Social cohesion is positively related to mental health outcomes and happiness (Cramm et al., 2013). Asserts that various types of freedom, including the freedom of social interaction based on trust, have considerable intrinsic value (Sen, 1999). Determining Pesindon as a batik tourism village in Pekalongan City has a binding positive impact where the relationship that occurs provides a symbiotic mutualism in the context of work professionalism and cultural diversity that is useful for each individual and society. For more details, it can be seen in the social impact chart of the determination of the Pesindon batik tourism village (Figure 2). The communication that occurs is getting better between each other so that groups or communities are getting closer and helping each other.

The socio-cultural impact and changes in values that are realized through increased harmonization after the establishment of Pesindon as a batik tourism village in Pekalongan between workers and batik entrepreneurs can be seen in 
the following quotes: "The relationship is now getting better. Welfare is also better since Pesindon became a batik village" (interview with study results). Another interview excerpt states the following: "As an employee, I have a good relationship with employers, are often assisted and get closer. Usually, employers ask for my help to prepare tools, arrange things if there are activities or events" if overtime work is often given extra money and also given food (interview study results).

It is not only workers engaged in production who feel the changing relationship between batik entrepreneurs and batik workers, but workers in the service sector with consumers, commonly referred to as boutique or showroom guards, also feel the social relationship between workers and batik entrepreneurs is getting better. Social change has had a significant influence on the shape of the tourism market (Fratu, 2011; Martin and Mason, 1987). The excerpt from an interview with one of the showroom guards said: "I feel happy working here. The relationship with the owner is good. I worked here after Pesindon was inaugurated as a batik tourism village. Until now, I have often communicated with entrepreneurs. The important thing is to maintain the confidence of entrepreneurs" (study interview).

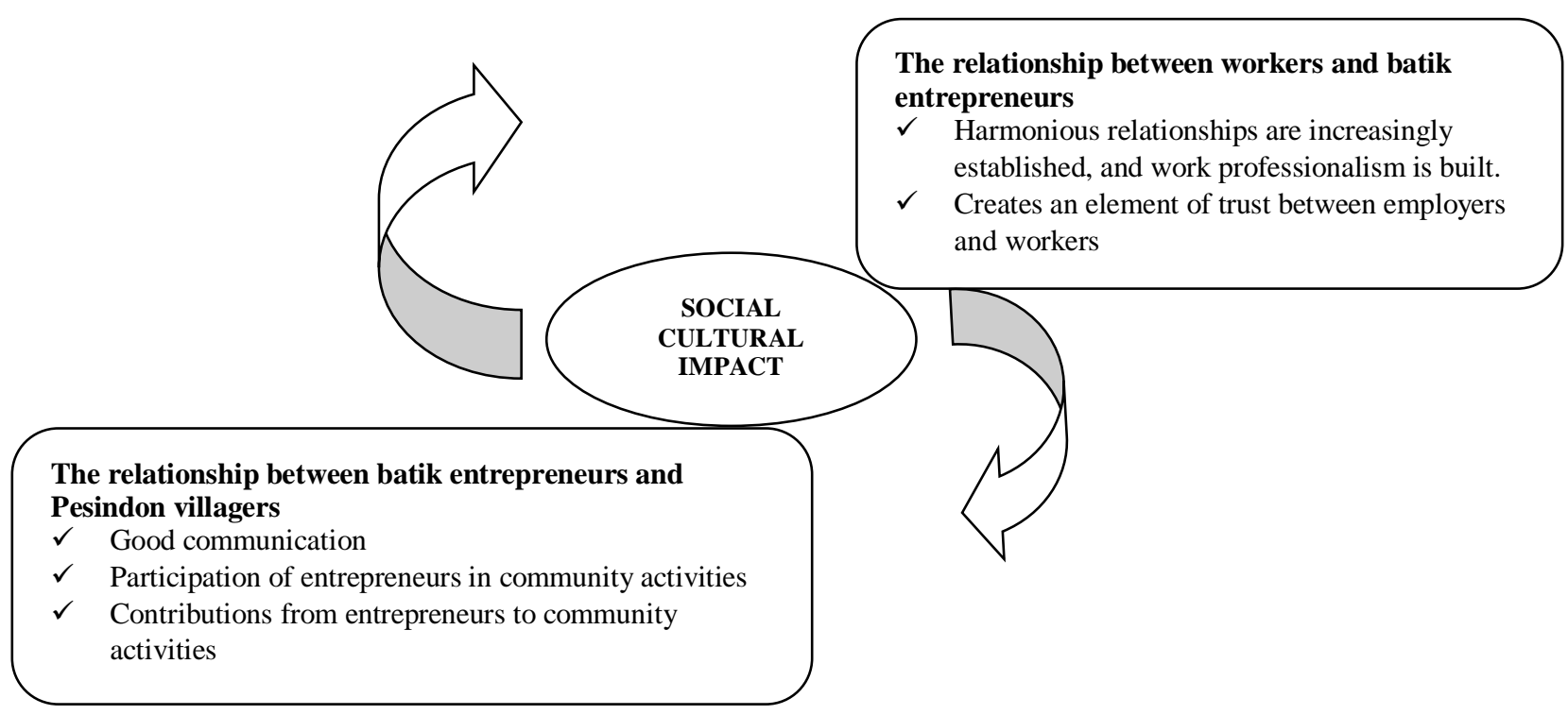

Figure 2. Results of the Study on the Social Impact of Designating a Tourism Village for Batik Pesindon

In the batik tourism village, the social impact caused is familial and the impact of a mutually beneficial professional relationship between workers and batik entrepreneurs. The establishment of Pesindon as a batik tourism village in Pekalongan City has positively impacted the relationship between batik entrepreneurs and workers. A better relationship between workers and batik entrepreneurs is increasingly being created. A pattern of relationships between entrepreneurs and batik workers indicates a symbiotic relationship of mutualism where workers make a living by working as batik workers. In contrast, entrepreneurs need services from workers to produce a batik or market it. As is the case in functionalism theory, society is seen as an organized network of cooperating groups that work relatively according to a set of rules and values shared by most of society. Society is seen as a stable system with a tendency towards balance, namely maintaining a harmonious and balanced work system. Patterns arise because they are functionally sound. Behavioral patterns arise to meet needs and disappear when needs change (Horton and Chester, 1999); Van den Berghe emphasizes this in Robert Lauer's writings rewritten by (Hatu, 2011; Nasith, 2017), looking at general characteristics from a functional perspective. Structural changes to society must be analyzed as a whole in a system consisting of interrelated parts. While the relationship of cause and effect is "plural and reciprocal." The social system is always in a state of "dynamic equilibrium," adjustment to the forces that impinge on the system creates minimal changes.

The relationship between batik entrepreneurs and the village community in the Pesindon batik tourism village is also well established. From the study results conducted through interviews with several native residents of the Pesindon batik tourism village, batik workers, and several business people in the Pesindon batik tourism village, it turned out that the statements from the three parties were the same in their narratives. For example, during an interview conducted with one of the resource persons as a resident in Kampung Pesindon, he stated that the relationship between him and the people who live in the Pesindon batik tourism village and the businessmen living in Pesindon Village is perfect. Here is his narrative: "I have good relations with batik entrepreneurs. The villagers are also evenly distributed, no one has problems with batik entrepreneurs in the village" (study interview). Statements from other sources also support this. Here is what he said:

"The batik entrepreneurs, apart from coming from outside the village, are also partly from within the Pesindon village itself; their relationship is good with the community. Although some of them are busy outside, they still participate in activities in the village" (interview with the study results). This is also in line with other sources. Where the quote of his narrative is as follows: "Batik entrepreneurs or batik workers are the same; they have a good relationship, there are no problems with the residents" (interview with the study results). The excellent relationship between the entrepreneurs and the residents of Pesindon village can also be seen from the contribution given by the entrepreneurs to the Pesindon residents; the entrepreneurs do not hesitate to give batik to the Pesindon residents who come. Here are quotes from residents: 
"You can say it is excellent. Entrepreneurs often share sustenance. The other thing is that these entrepreneurs are very friendly, and sometimes even when I visit, they are given batik, both in the form of stamped batik and written batik" but during a pandemic like this, we also have to know ourselves and use health protocols (interview study results).

Another thing that happened when several activities were held in the Pesindon batik village, almost every batik entrepreneur made a meaningful contribution to enliven the activity (if it was not a pandemic) as an example of community activities in cooperation. Although these entrepreneurs cannot always participate in cooperation, they provide some "snacks" or even money to participate as members of the village community. Another example is in the absence of a pandemic when at the commemoration of Indonesia's Independence Day batik entrepreneurs besides participating in competitions, it turns out that the batik entrepreneurs also gave the most significant donations in the event. This is following the statement of one of the secretariat administrators as well as Pesindon batik workers, namely: "If not during a pandemic like this, entrepreneurs usually take part in village activities, like a few years ago, when there were seventeen activities, each entrepreneur gave various gifts. Some are in the form of money, bicycles, cloth or batik clothes". (Study interview). This is reinforced by the testimony of another informant, a resident of Pesindon Village. Here is the statement:

"At normal times and there are no coronavirus or pandemic, batik entrepreneurs usually participate in village activities. Even ordinary batik entrepreneurs are the main donors during village activities. Like yesterday, during the Independence Day commemoration, there was a "pucang competition" on the river, which has become our culture, and the prize is up to five million. The participants are residents as well as batik workers as well. Sometimes some give an additional one million, five hundred thousand and some even give TV prizes directly" (interview with the study results). Besides participating in the activities held in Pesindon Village, it turns out that several activities were initiated by batik entrepreneurs in the Pesindon batik tourism village. Based on the results of interviews that have been carried out, it is found that the determination of Pesindon as a batik tourism village has a socio-cultural impact and changes in values on the relationship between Pesindon batik entrepreneurs and Pesindon residents. The relationship is getting better. In addition to participating in activities at Pesindon, batik entrepreneurs also contributed to these events. The social interaction that occurs is getting higher and more positive; even batik entrepreneurs are the most prominent donors and the initiators of various events in Pesindon Village.

\section{Social Values Changes}

Before establishing Pesindon as a batik tourism village, there was no organizational structure or secretariat, so the direction, purpose, and work patterns did not have a good target and orientation. The establishment of Pesindon as a batik tourism village provides renewal so that the organizational structure of Pesindon is also formed by outlining the main tasks of the functions of each existing field, of course, by having its vision. This mission changes the value of the existence of the Pesindon village. The change in social structure can be proven by forming a systematic organization in the Pesindon batik tourism village. The formed organizational structure results in social interaction, which causes frequent intensity in communicating, both among workers and workers, workers with employers, and entrepreneurs with the community. Individually humans differ concerning the presence of demographic, physiological, and psychological variables, including age, gender, social status, health, intelligence, temperament, and life circumstances. These differences are due to varying degrees of genetic causation, inherited wealth or social position, and individual experiences and achievements (Latané, 1996).

Changes in the value of the Pesindon village can also be seen from the tourism sector, which has a significant impact on generating community welfare; this is in line with the view (Urtasun and Gutiérrez, 2006) where, (1) the scale of tourism, measured in terms of per capita, (2) the distribution of tourism that does not evenly distribute throughout the region, namely, the tendency of agglomeration, and (3) the level of development of the host community in economic activities other than tourism. Through this, it becomes clear that the increase and expansion of the tourism market, as well as the creation of more prominent and more tourist destinations, or the growth of the tourism industry as a whole which is expected to progress in the coming decades like never before, will have a significant effect on the economy, cultural identity, as well as the physical environment (Risteskia et al., 2012). Tourism destinations are increasingly competitive and complex businesses and involve coordination between economic, social, and geographical factors (Buhalis and Amaranggana, 2014; Carlsen, 1999). Understanding the social impact of tourism on society is very important for the government so that actions can be taken to reduce the possibility of community reactions to tourists and tourism development (Deery et al., 2012). The fewer residents are affiliated with tourism work, the less affluent they are, and the less peripheral they feel, the more they are affected by the social consequences of tourism development (Chaperon and Bramwell, 2013; Mansfeld, 1992). The study (Pizam, 1978) stated that most of the impacts of tourism studies were limited to an analysis of the economics and benefits that occurred in the area, but in this study, apart from economic factors, sociocultural changes and changes in values could not be underestimated as the impact of establishing Pesindon as a Batik tourism village. In the city of Pekalongan. The existence of the batik tourism village has also changed, where when we start entering the Pesindon batik tourism village, we will easily find the location of a place or person we are looking for. Almost everyone who lives in Pesidon Village knows one another, even they are very familiar. For the residents of Pesindon, the establishment of Pesindon as a batik tourism village is a form of reality from their dream so far.

Horton's functional theory is seen in relationships between entrepreneurs and batik workers in the Pesindon batik tourism village. The existence of socio-cultural impacts and changes in values resulting from the determination of Pesindon as a batik tourism village that impacts the relationship between batik entrepreneurs and batik workers is not disputed by one of the batik entrepreneurs in the Pesindon batik tourism village. Here is his narrative: "I like the workers. They are people with high fighting spirits. Every day I always work with enthusiasm and also full of jokes, when I visit. Sometimes they joke together, and I think they are part of the family. The progress and decline of the batik business cannot be separated from the 
role of the batik itself. Especially when Pesindon is set to become a batik tourism village, the need for production is higher so that they work more enthusiastically and sometimes even have to work overtime. When guests arrive, they are served well. If the batik is advanced, the orders are large, and the impact will be on them too" (interview with the study results).

The Pesindon community, after its stipulation as a batik tourism village step by step, led to a social change and a change in values. The relationships that occur in it lead to professional work to meet the needs of each individual, as stated by Piotr Sztompka in Tonnies on the theory of societal change (Tonnies, 1887). The theory of societal change by Ferdinand Tonnies is a theory of social change that includes changes in Gemeinschaft and Gesellschaft. Gemeinschaft is a values-oriented, aspirational, role-playing situation and sometimes an original habit that dominates social forces. So for him, indirectly, Gemeinschaft arises from within the individual, and there is a desire to have a relationship or relationship based on similarities in desire and action. Individuals, in this case, are defined as the glue and support of social forces connected to their friends and relatives (family), with which they build emotional relationships and interactions of one individual with other individuals. Status is considered to be based on birth and limitations of mobilization and the individual's known unity of place in society. While Gesellschaft (which is defined as a society or modern society-the term Piotr Sztompka). After previously Weber asserted that he saw that societal change is seen in the tendency towards rationalization of social life and social organization in all areas such as instrumental considerations, emphasis on efficiency, distance from tradition and emotion, impersonality, bureaucratic management (Tonnies, 1887). The points in Gesellschaft can be seen in the pattern of relationships that occur between batik entrepreneurs and batik workers. The rationality of social life, instrumental considerations, emphasis on efficiency, distance from tradition, impersonality, and bureaucratic management have begun to enter the joints of life. This is another impact of the determination of Pesindon as a batik tourism village in Pekalongan City.

\section{CONCLUSION}

The socio-cultural impact and changes in values on Pesindon Village, Pekalongan City after the stipulation of Pesindon Village as a batik tourism village can be seen from the increasingly friendly and harmonious community of Pesindon Village residents. The intensity of direct interaction between entrepreneurs and batik workers and the increasingly visible changes in society in the form of Gesellschaft can be seen in the pattern of relationships between batik entrepreneurs and batik workers and batik entrepreneurs and community members. A new culture that is brought up with activities carried out with batik nuances takes place continuously; because of this, it indirectly becomes a culture and power that eventually takes root in culture and is carried out continuously. Changes in social values and structures include changes in the types of institutions in Pesindon, namely the birth of a secretariat for the Pesindon batik tourism village. The determination of Pesindon as a batik tourism village impacts changing status and roles in society.

\section{Acknowledgement}

This paper is part of a dissertation project, so we would like to thank the Universitas Negeri Semarang Postgraduate Program for approving the selection of this dissertation topic. Also, I would like to thank the Ministry of Research, Technology and Higher Education of the Republic of Indonesia for supporting the funding of this research.

\section{REFERENCES}

Adger, W.N., Barnett, J., Brown, K., Marshall, N., \& O’brien, K. (2013). Cultural dimensions of climate change impacts and adaptation. Nature Climate Change, 3(2), 112-117. https://doi.org/10.1038/nclimate1666

Ali, M.S.S., Salman, D., \& Mappangaja, R. (2015). Social Capital And Economic Behavior Of Farmers. International Journal of Scientific \& Technology Research, 4(1), 89-91. https://www.ijstr.org/final-print/jan2015/Social-Capital-And-Economic-Behavior-Of-Farmers.pdf

Amijaya, S.Y., Seliari, T., \& Oentoro, K. (2019). Realizing Smart Villages Through Community Cultural and Economic Tourism Management (Indonesian Version). Research Fair Unisri 2019, 3(1), 496-504. http://dx.doi.org/10.33061/rsfu.v3i1.2610

Bahruddin, M., \& Nugraha, E.F.S. (2013). Communities of Kampung Batik Jetis Sidoarjo: Between Maintaining Written Batik as a Local Cultural Product and Economic Contribution (Indonesian Version). Seminar Nasional \& Workshop: Peningkatan Inovasi Dalam Menanggulangi Kemiskinan, (April 2008). https://repository.dinamika.ac.id/id/eprint/1088/

Becker, H.A. (2001). Social impact assessment. European Journal Of Operational Research, 3(1), 3. https//doi.org/10. 1080/07349165.1984.9725505

Bourdieu, P. (1986). The forms of capital. In J. Richardson (Ed.), Handbook of Theory and Research for the Sociology of Education, 241-58, Westport, CT: Greenwood.

Buhalis, D., \& Amaranggana, A. (2014). Smart tourism destinations. In Information and communication technologies in tourism, 553564. https://link.springer.com/chapter/10.1007/978-3-319-03973-2_40

Caldwell, N.D., Roehrich, J.K., \& George, G. (2017). Social value creation and relational coordination in public-private collaborations. 44(0), 1-38. https://doi.org/10.1111/joms.

Carlsen, J. (1999). A systems approach to island tourism destination management. Systems Research and Behavioral Science, 16(4), 321-327. https://doi.org/10.1002/(SICI)1099-1743(199907/08)16:4<321::AID-SRES255>3.0.CO;2-5

Chaperon, S., \& Bramwell, B. (2013). Dependency and agency in peripheral tourism development. Annals of Tourism Research, 40(1), 132-154. https://doi.org/10.1016/j.annals.2012.08.003

Cote, M., \& Nightingale, A.J. (2012). Resilience thinking meets social theory: Situating social change in socio-ecological systems (SES) research. Progress in Human Geography, 36(4), 475-489. https://doi.org/10.1177/0309132511425708

Cramm, J.M., Van Dijk, H.M., \& Nieboer, A.P. (2013). The importance of neighborhood social cohesion and social capital for the well being of older adults in the community. Gerontologist, 53(1), 142-150. https://doi.org/10.1093/geront/gns052

Creswell, J.W. (2014). Research Design: Qualitative, Quantitative and Mixed Methods Approaches. Thousand Oaks, CA, Sage Publication.

Deery, M., Jago, L., \& Fredline, L. (2012). Rethinking social impacts of tourism research: A new research agenda. Tourism Management, 33(1), 64-73. https://doi.org/10.1016/j.tourman.2011.01.026

Fratu, D. (2011). Factors of influence and changes in the tourism consumer behaviour. Bulletin of the Transilvania University of Brasov. Economic Sciences. Series V, 4(1), 89-104. 
Fukuyama, F. (1997). The End of Order. The Social Market Foundation, London.

Gómez-Limón, J.A., Vera-Toscano, E., \& Garrido-Fernández, F.E. (2014). Farmers' contribution to agricultural social capital: Evidence from southern Spain. Rural Sociology, 79(3), 380-410. https://doi.org/10.1111/ruso.12034

Harris, J.R. (1995). Where is the child's environment? A group socialization theory of development. Psychological Review, 102(3), 458489. https://doi.org/10.1037/0033-295X.102.3.458

Hatu, R. (2011). Socio-cultural changes in rural communities: A Theoretical-Empirical Review (Indonesian Version). Journal Inovasi, 8(4), 1-11. https://ejurnal.ung.ac.id/index.php/JIN/article/view/721

Hermawan, H. (2016). The Impact of Nglanggeran Tourism Village Development on the Local Community Economy (Indonesian Version). Jurnal Pariwisata, 3(2), 60-70. https://ejournal.bsi.ac.id/ejurnal/index.php/jp/article/view/1383

Hjarvard, S. (2008). The Mediatization of Society. Nordicom Review, 29(2), 102-131. https://doi.org/10.1515/nor-2017-0181

Hopkins, N. (2011). Religion and Social Capital : Identity Matters. 540, 528-540. https://doi.org/10.1002/casp

Horton, P.B., \& Chester, L.H. (1999). Sociology Volume 1 Sixth Edition (Indonesian Version). Terjemahan Aminudin Ram dan Tita Sobari, Jakarta, Erlangga.

Johnson, S.G., Schnatterly, K., Hill, A.D., \& Hill, A.D. (2013). Journal of Management. https://doi.org/10.1177/0149206312463938

Komariah, K., Razzaq, A.R.B.A., Nugraheni, M., Lastariwati, B., \& Mahfud, T. (2020). The antecedent factor of tourists' intention to consume traditional food. GeoJournal of Tourism and Geosites, 32(4), 1209-1215. 5. https://doi.org/10.30892/gtg.32403-559

Krupka, E., \& Weber, R.A. (2009). The focusing and informational effects of norms on pro-social behavior. Journal of Economic Psychology, 30(3), 307-320. https://doi.org/10.1016/j.joep.2008.11.005

Lancee, B. (2010). The economic returns of immigrants' bonding and bridging social capital: The case of the Netherlands. International Migration Review, 44(1), 202-226. https://doi.org/10.1111/j.1747-7379.2009.00803.x

Latané, B. (1996). Dynamic Social Impact: The Creation of Culture by Communication. Journal of Communication, 46(4), 13-25. https://doi.org/10.1111/j.1460-2466.1996.tb01501.x

Leyden, D.P., \& Link, A.N. (2015). Toward a theory of the entrepreneurial process. Small Business Economics, 44(3). https://doi.org/10.1007/s11187-014-9606-0

Mahfud, T., Triyono, M.B., Sudira, P., \& Mulyani, Y. (2020). The influence of social capital and entrepreneurial attitude orientation on entrepreneurial intentions: the mediating role of psychological capital. European Research on Management and Business Economics, 26(1). https://doi.org/10.1016/j.iedeen.2019.12.005

Mahfud, Tuatul, Pardjono, \& Lastariwati, B. (2019). Chef's competency as a key element in food tourism success: A literature review. Geojournal of Tourism and Geosites, 26(3), 1057-1071. https://doi.org/10.30892/gtg.26329-417

Mahmoudi, H., Renn, O., Vanclay, F., Hoffmann, V., \& Karami, E. (2013). A framework for combining social impact assessment and risk assessment. Environmental Impact Assessment Review, 43, 1-8. https://doi.org/10.1016/j.eiar.2013.05.003

Mansfeld, Y. (1992). Group-Differentiated Perceptions of Social Impacts Related to Tourism Development. Profeysional Geographer, 44(4), 12-17. https://doi.org/10.1111/j.0033-0124.1992.00377.x

Martin, W.H., \& Mason, S. (1987). Social trends and tourism futures. Tourism Management, 8(2), 112-114. https://doi.org/10. 1016/0261-5177(87)90012-4

Mazumdar, S., Learnihan, V., Cochrane, T., \& Davey, R. (2018). The built environment and social capital: A systematic review. Environment and Behavior, 50(2), 119-158. https://doi.org/10.1177/0013916516687343

Moore, C.B., Payne, G.T., Autry, C.W., \& Griffis, S.E. (2018). Project Complexity and Bonding Social Capital in Network Organizations. Group and Organization Management, 43(6), 936-970. https://doi.org/10.1177/1059601116650556

Nasith, A. (2017). An overview of social change in the perspective of the sociology of education (Indonesian Version). 661-670. https://semnas.unikama.ac.id/lppm/prosiding/2017/alnasit.pdf

Nemoto, T. (1998). Subjective norms toward social support among Japanese American elderly in New York City: Why help does not always help. Journal of Community Psychology, 26(4), 293-316. https://doi.org/10.1002/(sici)1520-6629(199807)26:4<293::aid-jcop1>3.3.co;2-k

Pitana, I.G.I.K.S.D. (2009). Pengantar Ilmu Pariwisata. Yogyakarta :Penerbit Andi.

Pizam, A. (1978). Tourism's Impacts: The Social Costs to the Destination Community as Perceived by Its Residents. Journal of Travel Research, 16(8), 8-12. https://doi.org/10.1177/004728757801600402

Postelnicu, L., \& Hermes, N. (2018). The economic value of social capital. International Journal of Social Economics, 45(6), 870-887. https://doi.org/10.1108/IJSE-03-2017-0104

Risteskia, M., Kocevskia, J., \& Arnaudov, K. (2012). Spatial Planning and Sustainable Tourism as Basis for Developing Competitive Tourist Destinations. Procedia - Social and Behavioral Sciences, 44, 375-386. https://doi.org/10.1016/j.sbspro.2012.05.042

Sen, A. (1999). Development as Freedom. https://doi.org/10.9774/gleaf.978-1-907643-44-6_30

Setyanto, A.R., Samodra, B.R., \& Pratama, Y.P. (2015). Kajian Strategi Pemberdayaan UMKM Dalam Menghadapi Perdagangan Bebas Kawasan ASEAN (Studi Kasus Kampung Batik Laweyan). Etikonomi, 14(2), 205-220. https://doi.org/10.15408/etk.v14i2.2271

Stephens, N.M., Markus, H.R., \& Phillips, L.T. (2014). Social Class Culture Cycles: How Three Gateway Contexts Shape Selves and Fuel Inequality. Annual Review of Psychology, 65(1), 611-634. https://doi.org/10.1146/annurev-psych-010213-115143

Stoletov, A. (2016). Social creativity and phenomenon of success in postindustrial society. Creativity Studies, 9(2), 141-150. https://doi.org/10.3846/23450479.2016.1223765

Taufiqoh, B.R., Nurdevi, I., \& Khotimah, K. (2018). Batik as Indonesian Cultural Heritage (Indonesian Version). Seminar Nasional Bahasa Dan Sastra, 58-65. http://research-report.umm.ac.id/index.php/SENASBASA/article/view/2220

Tonnies, F. (1887). Gemeinschaft dan geselschaft. Googgle Books. Co.id.

Tulin, M., Lancee, B., \& Volker, B. (2018). Personality and Social Capital. Social Psychology Quarterly, 81(4), 295-318. https://doi.org/10.1177/0190272518804533

Urtasun, A., \& Gutiérrez, I. (2006). Tourism agglomeration and its impact on social welfare: An empirical approach to the Spanish case. Tourism Management, 27(5), 901-912. https://doi.org/10.1016/j.tourman.2005.05.004

Wahyuni, S., Handini,Y.D., \& Khristanto,W. (2017). Triple Helix (ABG) Approach in the Development of the Tuban Batik Tourism Village in Tuban Regency (Indonesian Version). LSP-Jurnal Ilmiah Dosen Unej. http://repository.unej.ac.id/handle/123456789/79150

Wallis, J., Killerby, P., \& Dollery, B. (2004). Social economics and social capital. International Journal of Social Economics, 31(3), 239-258. https://doi.org/10.1108/03068290410518238

Xu, X., Yao, Z., \& Teo, T.S.H. (2019). Moral Obligation In Online Social Interaction: Clicking The "like" Button. Journal Pre-Proof, 57(7). https://doi.org/10.1016/j.apcatb.2019.118214

Zissi, A., Tseloni, A., \& Skapinakis, P. (2010). Exploring social capital in rural settlements of an Islander region in Greece. Journal of Community \& Applied Social Psychology, 20(2), 125-138. https://doi.org/10.1002/casp.1024 